\title{
Forensic Sciences: The Genesis of a New Open Access Journal Focused on the Latest Scientific Advances
}

\author{
Ricardo Jorge Dinis-Oliveira ${ }^{1,2,3}$ (D) \\ 1 IINFACTS-Institute of Research and Advanced Training in Health Sciences and Technologies, \\ Department of Sciences, University Institute of Health Sciences (IUCS), CESPU, CRL, Rua Central de Gandra, \\ 1317, 4585-116 Gandra, Portugal; ricardinis@sapo.pt or ricardo.dinis@iucs.cespu.pt or ricardinis@med.up.pt \\ 2 Department of Public Health and Forensic Sciences, and Medical Education, Faculty of Medicine, \\ University of Porto, 4200-319 Porto, Portugal \\ 3 UCIBIO, REQUIMTE, Laboratory of Toxicology, Department of Biological Sciences, Faculty of Pharmacy, \\ University of Porto, 4050-313 Porto, Portugal
}

Received: 9 October 2020; Accepted: 10 October 2020; Published: 13 November 2020

Nowadays, and from a scientific point of view, Forensic Sciences are a fascinating "brave new world" that also attracts media attention due to the constant challenges that forensic scientists face. They are full of surprises and encourage everyday more and more researchers to produce a more scientific basis for routine forensic expertise. The complexity of Forensic Sciences arises from its great diversity of disciplines (broadly characterized into chemical, biological, and physical sciences) that offer scientific insights due to the degree of subspecialization of many of them, the multidisciplinary and mixed nature of Forensic Sciences examinations, their articulation under various laws, and in particular, due to the fact that they work directly or indirectly with very vulnerable people whose fundamental rights may be limited [1]. One of the most important aspects that characterizes Forensic Sciences and distinguishes it from other sciences is the need to respect the "chain of custody" when dealing with evidence. Moreover, Forensic Sciences also offers a new world of opportunities and challenges to research in all scientific areas [2].

The concept of "Forensic Sciences" has been subject to several interpretations by different authors, namely due to the influence of each country or region's judicial and judiciary system. According to the Oxford English Dictionary, the term "forensic" comes from the Latin word forennsis (meaning marketplace or forum) [3]. It was originally used to identify areas/forums in ancient Rome where the Senate met to debate business, public, and governmental affairs and where trials were held. The accused and accuser presented their considerations and the one with the best argument won [3,4]. Even today, high school or university teams that compete in debates or public speaking are called "forensic teams". After its first appearance in English vocabulary in 1659, its modern usage of "forensic" was gradually limited to the field of criminal investigation. Therefore, many people consider that Forensic Sciences are sciences of the forum, or Law, especially Criminal Law, leading to the idea that Forensic Sciences and crime always go hand in hand; this is not necessarily the case, since today we are broadly speaking about the application of Forensic Sciences to matters of the Law [1,4], particularly in Health and Life Sciences. In turn, the word "science" refers to the collection of systematic methodologies used to increasingly understand the physical world and, in some cases, to make it possible to predict future occurrences. In English, the word "science" came from the old French words "science" and "escience", meaning knowledge, learning, application, and a corpus of human knowledge; notwithstanding this, the term originally came from the Latin word scientia, which meant knowledge, a knowing, expertness, or experience. By the late 14th century, science meant collective knowledge in English.

In the history of Forensic Sciences, Ambroise Paré (1510-1590; Figure 1) should be remembered. He was a barber surgeon who systematically studied the effects of violent death on internal organs and he is considered to be one of the fathers of surgery and modern Forensic Pathology. 


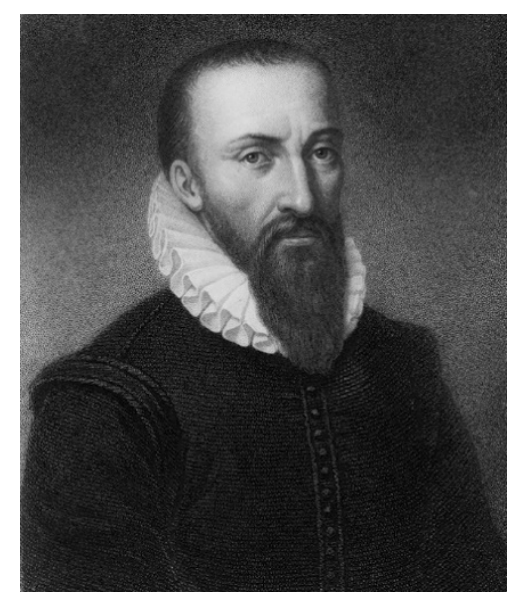

Figure 1. Ambroise Paré (1510-1590), a French surgeon considered as one of the fathers of Forensic Sciences.

There are, therefore, separate disciplines within the Forensic Sciences. Hence, the Forensic Sciences journal aims to focus on all their scientific aspects, emphasizing the importance of a multidisciplinary approach in forensic investigation. This means that in some cases it is difficult to draw exact separation lines between some of the forensic disciplines, as certain practices and procedures may overlap, a fact easily understood in science. This new journal is an international, peer-reviewed, open-access journal related to the latest advances of Forensic Sciences, either in living beings or in the deceased. Thus, it will publish original articles, reviews, short communications, letters to the editor, case reports, technical notes, and commentaries, with no restriction on the length of the papers. Our main aim is to encourage scientists to dedicate their efforts to apply Forensic Sciences in the administration of justice. We will mainly discuss the principal/classical and also the emergent branches of Forensic Sciences that include: Bloodstain Pattern Analysis, Computer Forensics, Criminology, Document Examination, Forensic Accounting (also known as Forensic Accountancy or Financial Forensics), Forensic Anthropology, Forensic Archaeology, Forensic Art, Forensic Astronomy, Forensic Ballistics, Forensic Biomechanics, Forensic Botany, Forensic Chemistry, Forensic Engineering, Forensic Entomology, Forensic Genetics, Forensic Geology, Forensic Geomorphology, Forensic Geophysics, Forensic Journalism, Forensic Linguistics, Forensic Lophoscopy, Forensic Medicine (that embraces all aspects of forensic work of a medical nature, including Forensic Pathology), Forensic Meteorology, Forensic Microbiology, Forensic Nursing, Forensic Odontology, Forensic Palynology, Forensic Photography, Forensic Psychiatry, Forensic Psychology, Forensic Radiology, Forensic Seismology, Forensic Social Work, Forensic Toxicology, Handwriting Analysis, Investigation in Forest Fires, and also Wildlife Forensic Science, among others. A particular interest will be devoted to pedagogical and educational innovation of the teaching curriculums of multiple forensic disciplines [5].

The Editorial Board of Forensic Sciences invites high-quality contributions in the field of Forensic Sciences and wishes all future contributors and readers all the best for this new scientific project.

Funding: This research received no external funding.

Conflicts of Interest: The author has no conflict of interest to declare. No writing assistance was obtained in the production of this manuscript.

\section{References}

1. Dinis-Oliveira, R.J;; Magalhães, T. What Are Forensic Sciences? Concepts, Scope and Future Perspectives; Lidel-Edições Técnicas: Lisbon, Portugal, 2016.

2. Magalhães, T.; Santos, A.; Dinis-Oliveira, R.J. Forensic medicine: A forgotten world of opportunities and challenges for research. Arch. Med. Res. 2013, 44, 479-481. [CrossRef] [PubMed]

3. Simpson, J.; Weiner, E. The Oxford English Dictionary, 2nd ed.; Clarendon Press: Oxford, UK, 1989. 
4. Crispino, F.; Houck, M.M. Principles of Forensic Science. In Encyclopedia of Forensic Sciences; Siegel, J.A., Saukko, P.J., Houck, M.M., Eds.; Academic Press: Waltham, MA, USA, 2013; pp. 278-281. [CrossRef]

5. Magalhães, T.; Dinis-Oliveira, R.J.; Santos, A. Teaching forensic medicine in the University of Porto. J. Forensic Leg. Med. 2014, 25, 45-48. [CrossRef] [PubMed]

\section{Short Biography of Author}

Ricardo Jorge Dinis-Oliveira, PhD, European PhD, DSc, is a Forensic Sciences expert, namely in Toxicology and Forensic Medicine areas, and he contributes to scientific and academic activity in the areas of Toxicology and Pharmacology of Psychoactive Substances, Pesticides and Medicines in their preclinical, clinical and forensic aspects, and in Forensic Medicine, namely the development of mathematical models to calculate the postmortem interval, known as the Holy Grail of Forensic Sciences. He has supervised several Integrated Master's dissertations, Master's dissertations and Doctoral theses. He is a member of the Editorial Board and Ambassador of several International Scientific Journals. He is the author of more than 145 articles published (representing more than 4700 citations) in international journals, indexed by peer review, and author of about 35 book chapters, 4 books and 4 national and 3 international patents. He is the author of Guidelines in Forensic Sciences with an international scope, and has received recognition for his Pedagogical Excellence in Higher Education that resulted in international scientific publications. He is an Associate Professor with Aggregation at the University Institute of Health Sciences and of the Faculty of Medicine of University of Porto. He is an Integrated Researcher at UCIBIO-REQUIMTE-Applied Molecular Biosciences Unit/ Associated Laboratory for Green Chemistry, Clean Technologies and Processes and at the IINFACTS-Institute of Research and Advanced Training in Health Sciences and Technologies, where he has performed duties of Coordinator of the Forensic Sciences Research Line. He is the founder and current President of the Portuguese Association of Forensic Sciences (APCF) and was Vice-President of the Portuguese Society for the Study of Abuse and Neglect (SPECAN). The current $\mathrm{h}$ index is approximately 26, depending on the calculation platform.

Publisher's Note: MDPI stays neutral with regard to jurisdictional claims in published maps and institutional affiliations.

(C) 2020 by the author. Licensee MDPI, Basel, Switzerland. This article is an open access article distributed under the terms and conditions of the Creative Commons Attribution (CC BY) license (http://creativecommons.org/licenses/by/4.0/). 